\title{
Pemanfaatan Bottom Ash Sebagai Bahan Substitusi Agregat Halus Terhadap Kekuatan Beton
}

\author{
Agnes Claudia Posedung ${ }^{1}$, Frans Phengkarsa*2, Desy Sandy ${ }^{\star 3}$, \\ *1 Mahasiswa Program Studi Teknik Sipil, Universitas Kristen Indonesia Paulus, Makassar, Indonesia \\ agnesclaudia@gmail.com \\ *2*3 Dosen Program Studi Teknik Sipil, Universitas Kristen Indonesia Paulus, Makassar, Indonesia \\ fphengkarsa@hotmail.com dan sandy.mylife@yahoo.co.id
}

\begin{abstract}
ABSTRAK
Bottom ash merupakan hasil sisa pembakaran batu bara yang dapat bermanfaat untuk pemanfaatan penyusun campuran beton. Pada penelitian ini bottom ash digunakan sebagai bahan substitusi agregat halus dalam pembuatan beton. Bottom ash memiliki ukuran butir lebih besar dan lebih berat dengan karakteristik berwarna abu-abu gelap. Tujuan penelitian ini untuk mengetahui kekuatan beton yang menggunakan bottom ash sebagai bahan substitusi agregat halus. Persentase penggunaan bottom ash sebagai bahan substitusi agregat halus sebesar $0 \%, 25 \%$ dan $35 \%$. Penelitian dilaksanakan di Laboratorium Teknologi Bahan Universitas Kristen Indonesia Paulus Benda uji yang digunakan berupa silinder ukuran diameter $15 \mathrm{~cm}$ dan tinggi $30 \mathrm{~cm}$ sebanyak 36 buah. Pengujian yang dilakukan berupa pengujian kuat tekan, uji kuat tarik belah dan uji modulus elastisitas dengan mutu beton rencana $30 \mathrm{MPa}$. Dari hasil penelitian, untuk hasil uji kuat tekan diperoleh variasi bottom ash optimum pada penggunaan bottom ash 35\% dengan kuat tekan sebesar 33,764 MPa pada umur 28 hari, pengujian kuat tarik belah diperoleh variasi bottom ash optimum pada penggunaan bottom ash $35 \%$ dengan kuat tarik belah sebesar 3,253 MPa pada umur 28 hari sedangkan nilai modulus elastisitas tertinggi diperoleh pada penambahan bottom ash 35\% yaitu sebesar $27332.0255 \mathrm{Mpa}$. Dan diperoleh persentase hubungan kuat tarik belah untuk variasi bottom ash $0 \%, 25 \%$ dan $35 \%$ berturut-turut sebesar $8,007 \%, 8,983 \%$ dan $9,635 \%$ dari kuat tekan. Nilai tersebut memenuhi atau sesuai dengan yang ditentukan yaitu rata-rata berkisar antara $7 \%$ hingga $11 \%$ dari kuat tekannya dengan rata-rata berkisar $9 \%$. Dari variasi bottom ash yaitu 0\%, 25\% dan 35\% pada benda uji silinder , yang mencapai f'c $30 \mathrm{Mpa}$ adalah bottom ash dengan variasi $35 \%$ dan dapat digunakan sebagai bahan substitusi agregat halus.
\end{abstract}

Kata Kunci : bottom ash, kuat tekan, kuat tarik belah, modulus elastisitas

\begin{abstract}
Bottom ash is the result of coal combustion which can be useful for the use of concrete mix constituents. In this study, bottom ash is used as a substitute for fine aggregate in the manufacture of concrete. Bottom ash has a larger and heavier grain size with a characteristic dark gray color. The purpose of this study was to determine the strength of concrete using bottom ash as a substitute for fine aggregate. The percentage of the use of bottom ash as a substitute for fine aggregate is $0 \%, 25 \%$, and $35 \%$. The research was conducted at the Laboratory of Material Technology, Paulus University of Indonesia Christianity. The test objects used were 36 cylinders with a diameter of $15 \mathrm{~cm}$ and a height of $30 \mathrm{~cm}$. Tests conducted in the form of compressive strength test, split tensile strength test, and modulus of elasticity test with a concrete quality plan of $30 \mathrm{MPa}$. From the research results, for the compressive strength test results obtained the optimum bottom ash variation at the use of $35 \%$ bottom ash with a compressive strength of $33,764 \mathrm{MPa}$ at the age of 28 days, the split tensile strength test obtained the optimum variety of bottom ash at the use of bottom ash $35 \%$ with split tensile strength. of $3,253 \mathrm{MPa}$ at the age of 28 days while the highest modulus of elasticity was obtained at the addition of $35 \%$ bottom ash which was $27332.0255 \mathrm{Mpa}$. And the percentage of split tensile strength relationship for bottom ash variation is $0 \%, 25 \%$, and $35 \%$ of $8.007 \%, 8.983 \%$, and $9.635 \%$ of the compressive strength, respectively. This value meets or is by following per under with what is determined, namely the average ranges from $7 \%$ to $11 \%$ of the compressive strength with an average of around $9 \%$. From the variation of bottom ash, namely $0 \%, 25 \%$, and $35 \%$ in cylindrical specimens, which reaches f'c $30 \mathrm{Mpa}$ is bottom ash with a variation of $35 \%$ and can be used as a substitute for fine aggregate.
\end{abstract}

Keywords: bottom ash, strong concrete pull, elasticity modulus 


\section{PENDAHULUAN}

Seiring dengan berjalannya waktu perkembangan pengetahuan tentang beton, telah banyak industri yang telah mengganti bahan dasar campuran beton untuk mendapatkan hasil beton yang bermutu, ekonomis dan efisien. Salah satu bidang industri yang saat ini makin maju perkembangannya adalah industri batu bara. Dengan meningkatnya pertumbuhan industri batu bara maka makin meningkat pula limbah yang dihasilkan dan memiliki sifat yang dapat mencemari lingkungan seperti pencemaran udara, perairan dan penurunan kualitas ekosistem. Hal ini yang mendasari pemanfaatan limbah batu bara yaitu bottom ash sebagai agregat halus. Bottom ash merupakan abu dasar yang berbentuk seperti abu yang tertinggal dan dikeluarkan di bawah tungku pembakaran dari hasil sisa pembakaran batu bara. Bottom ash memiliki ukuran butir lebih besar dan lebih berat dengan karakteristik berwarna abu-abu gelap. Di kota Makassar, Sulawesi Selatan Pengudangan Parangloe Indah (PT.Makassar Tene) terdapat limbah bottom ash (abu dasar) dengan jumlah yang cukup besar sehingga memerlukan pengelolaan yang baik.

Tujuan penelitian untuk untuk mengetahui kuat tekan dan tarik belah dengan persentase bottom ash dalam campuran beton, dengan menggunakan variasi persentase bottom ash yaitu 0\%, 25\%, dan 35\% dengan menggunakan mutu beton yaitu f'c $30 \mathrm{MPa}$.

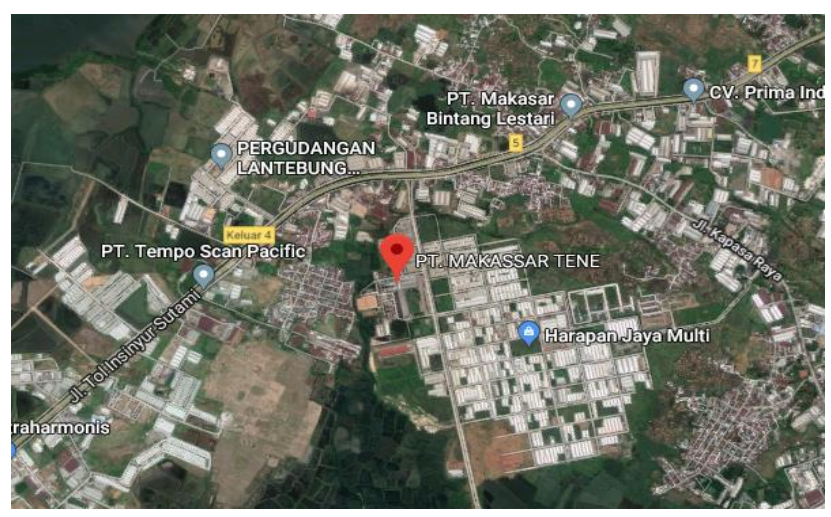

Gambar 1. Lokasi pengambilan sampel

Kota Makassar, Sulawesi Selatan jalan Ir. Sutami, No. 38 Kompleks Pengudangan Parangloe Indah (PT.Makassar Tene) adalah lokasi pengambilan bottom ash (abu dasar). Waktu penelitian direncanakan kurang lebih 1 bulan mulai bulan Mei Juli 2019. Semen yang digunakan adalah Semen Holcim, Portland Composite Cement (PCC) produk PT Holcim Indonesia Tbk. Agregat halus yang digunakan pada penelitian ini adalah abu batu yang berasal dari Sungai Jeneberang, Sulawesi Selatan. Agregat kasar yang digunakan pada penelitian ini adalah batu pecah yang berasal dari Sungai Jeneberang, Sulaswesi Selatan. Air yang digunakan pada penelitian ini adalah air dari PDAM.

Beberapa penelitian sejenis yaitu pemanfaatan limbah bottom ash dapat digunakan menjadi pengganti agregat halus dalam pembuatan beton dengan menurunkan kadar karbon [1], nilai slump tidak terlalu dipengaruhi oleh variasi abu dasar [2], pada pembuatan paving dengan memanfaatkan limbah abu dasar dengan tambahan kapur dapat digunakan meskipun kuat tekan belum maksimal [3], dengan penambahan abu dasar dapat meningkatkan daya serap bata semen tetapi menurunkan kuat tekan [4], Penurunan kekuatan dan flow ability terjadi pada abu dasar yang diayak dan sebaliknya untuk abu dasar yang ditumbuk [5], dengan menggunakan abu dasar sebagai pengganti agregat halus pasir Lumajang makan kekuatan dan workability beton HVFA semakin menurun. [6]

\section{METODE}

\section{Kuat Tekan Beton (Berdasarkan SNI 1974:2011)}

Kuat tekan beton adalah besarnya beban persatuan luas, yang menyebabkan benda uji beton hancur bila dibebani dengan gaya tekan tertentu, yang dihasilkan oleh mesin tekan.

Kuat tekan dihitung dari beban tekan maksimum yang dapat ditahan dibagi dengan luas penampang benda uji.

$f_{C}^{\prime}=\frac{P}{A}$

Keterangan:

$f_{c}^{\prime}=$ Kuat tekan $(\mathrm{MPa})$

$\mathrm{P}=$ Beban tekan maksimum yang dapat ditahan (Newton)

$\mathrm{A}=$ Luas penampang silinder diameter $15 \mathrm{~cm}$, tinggi $30 \mathrm{~cm}\left(\mathrm{~mm}^{2}\right)$

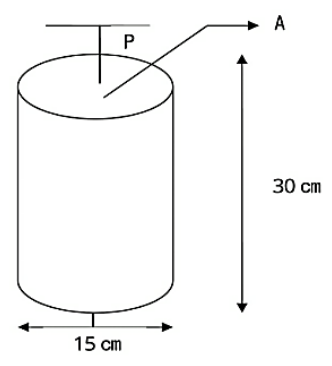

Gambar 2. Uji kuat tekan 


\section{Kuat Tarik Belah Beton (SNI 2491:2014)}

Kuat tarik belah adalah kuat tarik beton yang ditentukan berdasarkan kuat tekan belah dari silinder beton yang ditekan pada sisi panjangnya. Kekuatan tarik belah beton relative rendah, nilai kuat tekan dan tarik belah beton tidak berbanding lurus. Setiap uasaha perbaikan mutu kekuatan tekan hanya disertai dengan peningkatan kecil nilai kuat tariknya. Kekuatan tarik lebih sulit diukur dibandingkan dengan kekuatan tekan karena masalah penjepitan pada mesin

Pengujian tersebut menggunakan silinder beton berdiameter $150 \mathrm{~mm}$ dan panjang $300 \mathrm{~mm}$, diletakkan dengan arah memanjang di atas alat penguji kemudian beban tekan diberikan merata ke arah tegak lurus dari atas pada seluruh panjang silinder. Apabila kuat tarik terlampaui, benda uji terbelah menjadi dua bagian dari ujung ke ujung. Tegangan tarik yang timbul sewaktu benda uji tarik belah disebut split cylinder strength atau kuat tarik belah.

Berdasarkan SNI 2491:2014, nilai kuat tarik belah dapat dihitung dengan rumus:

$$
f_{c t}=\frac{2 P}{\pi L D}
$$

\section{Keterangan:}

$f_{c t}=$ Kuat tarik belah (MPa)

$\mathrm{P}=$ Beban uji maksimum $(\mathrm{N})$

$\mathrm{L}=$ Panjang benda uji silinder $(\mathrm{mm})$

$\mathrm{D}=$ Diameter benda uji silinder $(\mathrm{mm})$
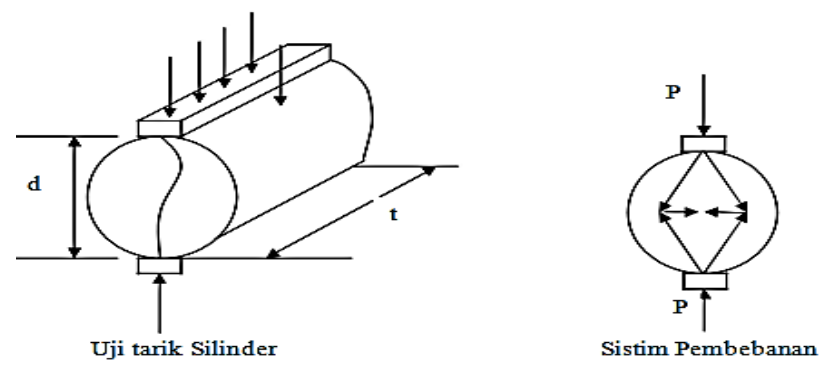

Gambar 3. Uji Tarik Belah

\section{Modulus Elastisitas Beton}

Modulus elastisitas $\left(E_{c}\right)$ merupakan properti mekanik dari struktur beton yang sangat penting. Pengujian modulus elastisitas beton dilakukan terhadap benda uji berbentuk silinder berdiameter $15 \mathrm{~cm}$ dan tinggi 30 $\mathrm{cm}$.

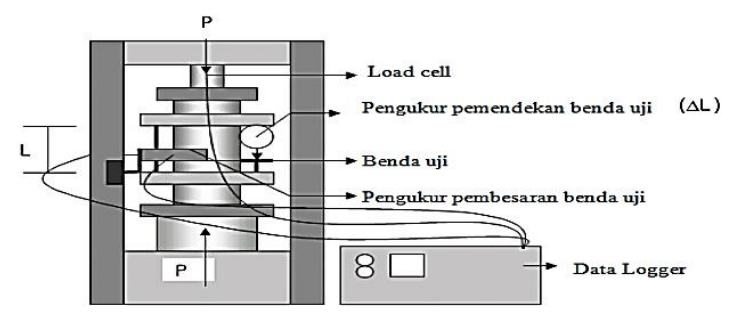

Gambar 4. Pengujian modulus elastisitas beton

Pada benda uji silinder dipasang dial gauge untuk mengukur pemendekan yang terjadi pada benda uji. Standar pengujian modulus elastisitas mengacu pada ASTM C 469 -02 "Standard Test Method for Static Modulus of Elasticity and Poisson's Ratio of Concrete in Compression". Besarnya modulus elastisitas dihitung dengan rumus:

$E_{C}=\frac{S 2-S 1}{\varepsilon 2-0,00005}$

(3)

dengan:

$E_{c}=$ modulus elastisitas beton (MPa)

$S_{2}^{c}=$ besar tegangan saat $40 \%$ beban batas (MPa)

$S_{1}=$ besar tegangan saat regangan $0,00005(\mathrm{MPa})$

$\varepsilon 2=$ regangan saat $40 \%$ beban batas 60

Modulus elastisitas adalah suatu ukuran dari kekakuan (stiffness) atau daya tahan bahan terhadap deformasi. Modulus elastisitas ditentukan dari perubahan tegangan terhadap regangan dalam batas elastisnya.

\section{Desain dan Jumlah Benda Uji}

Jenis benda uji yaitu silinder ukuran diameter $15 \mathrm{~cm}$ dan tinggi $30 \mathrm{~cm}$ untuk pengujian kuat tekan beton dan kuat tarik belah beton. Metode rancangan campuran beton yang digunakan adalah metode $\mathrm{ACl}$ dan Jumlah sampel sebanyak 36 sampel. FAS 0,43. 
Tabel 1. Jumlah benda uji untuk kuat tekan

\begin{tabular}{|c|c|c|c|c|c|c|c|}
\hline \multirow[t]{2}{*}{ No. } & \multirow[t]{2}{*}{ Kode } & \multirow{2}{*}{$\begin{array}{c}\text { Variasi } \\
\text { Presentase } \\
\text { Bottom ash }\end{array}$} & \multirow[t]{2}{*}{$\begin{array}{c}\text { Jenis } \\
\text { Pengujian }\end{array}$} & \multirow{2}{*}{$\begin{array}{c}\text { Bentuk } \\
\text { Benda } \\
\text { Uji }\end{array}$} & \multicolumn{3}{|c|}{$\begin{array}{l}\text { Jumlah dan } \\
\text { Umur Benda Uji }\end{array}$} \\
\hline & & & & & $\begin{array}{c}7 \\
\text { hari }\end{array}$ & $\begin{array}{l}21 \\
\text { hari }\end{array}$ & $\begin{array}{c}28 \\
\text { hari }\end{array}$ \\
\hline 1 & \multirow[b]{3}{*}{$\mathrm{BKT}$} & $0 \%$ & \multirow[b]{3}{*}{$\begin{array}{l}\text { Kuat } \\
\text { Tekan }\end{array}$} & \multirow{3}{*}{$\begin{array}{c}\text { Silinder } \\
\text { ukuran } \\
\text { diameter } \\
15 \mathrm{~cm} \\
\text { dan } \\
\text { tinggi } 30 \\
\mathrm{~cm}\end{array}$} & 3 & 3 & 3 \\
\hline 2 & & $25 \%$ & & & 3 & 3 & 3 \\
\hline 3 & & $35 \%$ & & & 3 & 3 & 3 \\
\hline
\end{tabular}

Tabel 2. Jumlah benda uji untuk kuat tarik belah

\begin{tabular}{|c|c|c|c|c|c|}
\hline \multirow[t]{2}{*}{ No. } & \multirow[t]{2}{*}{ Kode } & $\begin{array}{c}\text { Variasi } \\
\text { Presentase }\end{array}$ & \multirow[t]{2}{*}{$\begin{array}{c}\text { Jenis } \\
\text { Pengujian }\end{array}$} & \multirow{2}{*}{$\begin{array}{c}\text { Bentuk } \\
\text { Benda } \\
\text { Uji }\end{array}$} & $\begin{array}{c}\text { Jumlah dan Umur } \\
\text { Benda Uji }\end{array}$ \\
\hline & & Bottom ash & & & 28 hari \\
\hline 1 & \multirow[b]{3}{*}{ BTB } & $0 \%$ & \multirow{3}{*}{$\begin{array}{l}\text { Kuat } \\
\text { Tarik } \\
\text { Belah }\end{array}$} & \multirow{3}{*}{$\begin{array}{c}\text { Silinder } \\
\text { ukuran } \\
\text { diameter } \\
15 \mathrm{~cm} \\
\text { dan } \\
\text { tinggi } 30 \\
\mathrm{~cm}\end{array}$} & 3 \\
\hline 2 & & $25 \%$ & & & 3 \\
\hline 3 & & $35 \%$ & & & 3 \\
\hline
\end{tabular}

\section{Identifikasi Benda Uji}

Benda uji silinder ukuran diamater $15 \mathrm{~cm}$ dan tinggi $30 \mathrm{~cm}$, terdiri dari Beton dengan bottom ash sebagai bahan subsitusi agregat halus sebanyak 18 silinder untuk pengujian kuat tekan dan 6 silinder untuk kuat tarik belah. Beton tanpa bottom ash sebanyak 9 silinder untuk pengujian kuat tekan dan 3 silinder untuk kuat tarik belah. Pembuatan beton dengan menggunakan metode $\mathrm{ACl}$.

\section{HASIL DAN PEMBAHASAN}

\section{Karakteristik Agregat Kasar dan Halus}

Material yang digunakan adalah batu pecah yang berasal dari sungai Jeneberang dan abu batu yang berasal dari sungai Jeneberang. Pengujian karakteristik material agregat kasar dan halus dilakukan di Laboratorium Struktur dan Bahan Jurusan Teknik Sipil Universitas Kristen Indonesia Paulus meliputi Pemeriksaan Analisa Saringan, Pemeriksaan Berat Jenis dan Penyerapan, Pemeriksaan Berat Volume, Pemeriksaan Kadar Lumpur dan Pemeriksaan Kadar Air. Pengujian agergat didasarkan pada standar SNI.

Tabel 3. Hasil Rekapitulasi Pemeriksaan Karakteristik Agregat Halus

\begin{tabular}{ccccc}
\hline No. & Karakteristik & Hasil & Interval SNI & Keterangan \\
\hline 1 & Kadar Air & $3,305 \%$ & $3,00 \%-5,00 \%$ & Memenuhi \\
\hline 2 & Zat Organik & No. 1 & $<$ No. 3 & Memenuhi \\
\hline 3 & Kadar Lumpur & $1,318 \%$ & $0,20 \%-6,00 \%$ & Memenuhi \\
\hline 4 & Berat Volume Padat & $1,555 \mathrm{~kg} /$ liter & $1,4-1,9 \mathrm{~kg} / \mathrm{liter}$ & Memenuhi \\
\hline 5 & Berat Volume Gembur & $1,433 \mathrm{~kg} / \mathrm{liter}$ & $1,4-1,9 \mathrm{~kg} /$ liter & Memenuhi \\
\hline 6 & Berat Jenis SSD & 2,48 & $1,60-3,20$ & Memenuhi \\
\hline 7 & Absorpsi (Penyerapan) & $1,265 \%$ & $0,20 \%-2,00 \%$ & Memenuhi \\
\hline 8 & Modulus Kehalusan & $2,499 \%$ & $2,20-3,10$ & Memenuhi \\
\hline
\end{tabular}


Tabel 4. Hasil Rekapitulasi Pemeriksaan Karakteristik Bottom ash

\begin{tabular}{ccccc}
\hline No. & Karakteristik & Hasil & Interval SNI & Keterangan \\
\hline 1 & Kadar Air & $3,19 \%$ & $3,00 \%-5,00 \%$ & Memenuhi \\
\hline 2 & Zat Organik & No. 1 & $<$ No. 3 & Memenuhi \\
\hline 3 & Kadar Lumpur & $2,249 \%$ & $0,20 \%-6,00 \%$ & Memenuhi \\
\hline 4 & Berat Volume Padat & $1,469 \mathrm{~kg} /$ liter & $1,4-1,9 \mathrm{~kg} /$ liter & Memenuhi \\
\hline 5 & Berat Volume Gembur & $1,413 \mathrm{~kg} / \mathrm{liter}$ & $1,4-1,9 \mathrm{~kg} / \mathrm{liter}$ & Memenuhi \\
\hline 6 & Berat Jenis SSD & 2,27 & $1,60-3,20$ & Memenuhi \\
\hline 7 & Absorpsi (Penyerapan) & $1,73 \%$ & $0,20 \%-2,00 \%$ & Memenuhi \\
\hline 8 & Modulus Kehalusan & $2,475 \%$ & $2,20-3,10$ & Memenuhi \\
\hline
\end{tabular}

Tabel 5. Hasil Rekapitulasi Pemeriksaan Karakteristik Agregat Kasar

\begin{tabular}{ccccc}
\hline No. & Karakteristik & Hasil & Interval SNI & Keterangan \\
\hline 1 & Kadar Air & $0,566 \%$ & $0,50 \%-2,00 \%$ & Memenuhi \\
\hline 2 & Kadar Lumpur & $0,483 \%$ & $0,20 \%-1,00 \%$ & Memenuhi \\
\hline 3 & Berat Volume Padat & $1,619 \mathrm{~kg} /$ liter & $1,4-1,9 \mathrm{~kg} / \mathrm{lite}$ & Memenuhi \\
\hline 4 & Berat Volume Gembur & $1,475 \mathrm{~kg} /$ liter & $1,4-1,9 \mathrm{~kg} /$ lite & Memenuhi \\
\hline 5 & Berat Jenis SSD & 2,561 & $1,60-3,20$ & Memenuhi \\
\hline 6 & Absorpsi (Penyerapan) & $1,668 \%$ & $0,20 \%-2,00 \%$ & Memenuhi \\
\hline
\end{tabular}

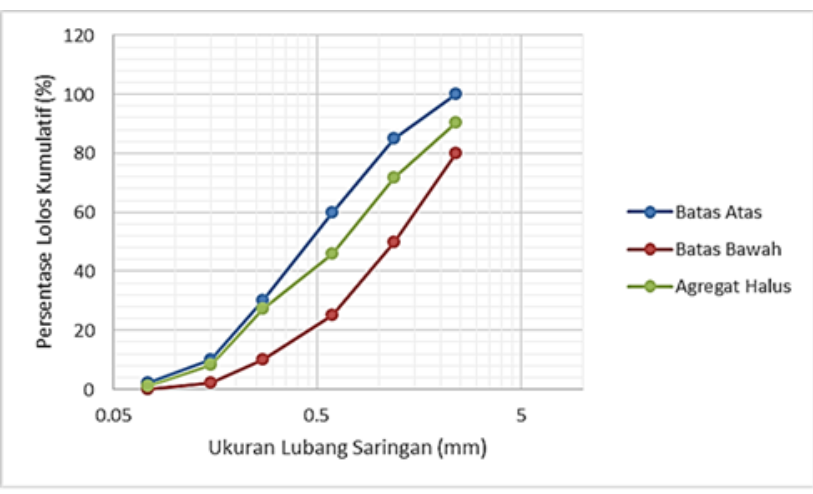

Gambar 5. Pembagian gradasi butiran agregat halus

\section{Mix Design}

Mix design dapat didefinisikan sebagi proses merancang dan memilih bahan yang cocok dan

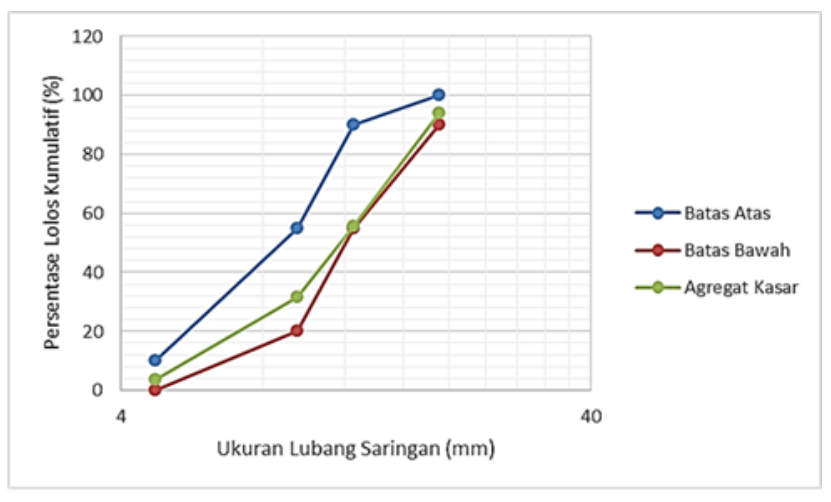

Gambar 6. Pembagian gradasi butiran agregat kasar

menentukan proporsi relatif dengan tujuan memproduksi beton dengan kekuatan tertentu. Dari hasil perhitungan mix design beton, diperoleh komposisi campuran dapat dilihat pada Tabel 6. 
Tabel 6. Kebutuhan bahan campuran beton untuk $1 \mathrm{~m}^{3}$ dengan variasi bottom ash

\begin{tabular}{cccc}
\hline \multirow{2}{*}{ Material } & \multicolumn{3}{c}{ Berat $\mathrm{kg} / \mathrm{m}^{3}$} \\
\cline { 2 - 4 } & Bottom ash 0\% & Bottom ash 25\% & Bottom ash 35\% \\
\hline Agregat Kasar & 1133,78 & 1133,78 & 1133,78 \\
\hline Agregat Halus & 599 & 449,25 & 389,35 \\
\hline Semen & 448,837 & 448,837 & 448,837 \\
\hline Air & 193 & 193 & 193 \\
\hline Bottom ash 25\% & - & 149,75 & - \\
\hline Bottom ash 35\% & - & - & 209,65 \\
\hline
\end{tabular}

\section{Hasil Pemeriksaan Kuat Tekan Beton}

Pengujian kuat tekan beton dilakukan pada saat benda uji berumur 7 hari, 21 hari dan 28 hari dengan menggunakan Compression Testing Machine untuk mendapatkan beban maksimum yaitu beban pada saat beton hancur ketika menerima beban tersebut ( $P_{\text {maks }}$ ) dalam satuan $\mathrm{KN}$.

Contoh Perhitungan :

Umur 28 Hari (Variasi Bottom ash 35\%):

$$
\begin{array}{lll}
\begin{array}{c}
\text { Beban Maksimum }(P) \\
\text { Luas Penampang }(A)
\end{array}= & 610 \mathrm{KN}=610000 \mathrm{~N} \\
\text { Kuat Tekan }\left(f_{c}^{\prime}\right)= & \frac{610000}{17671.459} & 17671.459 \mathrm{~mm}^{2} \\
& =\quad 34.519 \quad \mathrm{~N} / \mathrm{mm}^{2}= \\
34.519 \mathrm{MPa} &
\end{array}
$$

Hasil pengujian kuat tekan beton pada benda uji silinder dengan ukuran diameter $15 \mathrm{~cm}$ dan tinggi 30 $\mathrm{cm}$ pada umur beton 7 hari, 21 hari dan 28 hari dapat dilakukan uji kuat tekan di Laboratorium. Berikut hasil pengujian kuat tekan beton pada Tabel 7, 8, dan 9.

Tabel 9. Kuat tekan beton dengan campuran bottom ash pada umur 7 hari

\begin{tabular}{ccc}
\hline Variasi Bottom ash & Kuat Tekan Beton Aktual (Mpa) & Kuat Tekan Beton (Mpa) \\
\hline$B A 0 \%$ & 19,617 & 30,180 \\
\hline$B A 25 \%$ & 19,806 & 30,471 \\
\hline$B A 35 \%$ & 20,466 & 31,486 \\
\hline
\end{tabular}

Tabel 8. Kuat tekan beton dengan campuran bottom ash pada umur 21 hari

\begin{tabular}{ccc}
\hline Variasi Bottom ash & Kuat Tekan Beton Aktual (Mpa) & Kuat Tekan Beton (Mpa) \\
\hline$B A 0 \%$ & 28,766 & 30,280 \\
\hline$B A 25 \%$ & 29,237 & 30,776 \\
\hline$B A 35 \%$ & 29,898 & 31,471 \\
\hline
\end{tabular}

Tabel 9. Kuat tekan beton dengan campuran bottom ash pada umur 28 hari

\begin{tabular}{ccc}
\hline Variasi Bottom ash & Kuat Tekan Beton Aktual (Mpa) & Kuat Tekan Beton (Mpa) \\
\hline$B A 0 \%$ & 31,784 & 31,784 \\
\hline$B A 25 \%$ & 32,538 & 32,538 \\
\hline$B A 35 \%$ & 33,764 & 33,764 \\
\hline
\end{tabular}




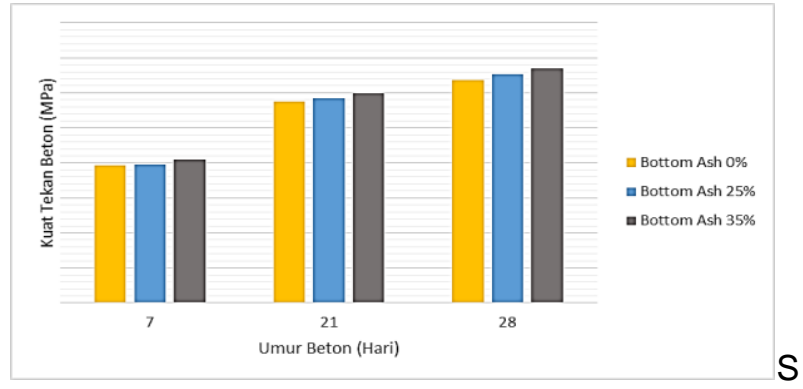

Gambar 7. Hubungan Antara Umur Beton Dengan Kuat Tekan Beton.

Dari gambar 7 menunjukkan bahwa kuat tekan beton dari beberapa variasi substitusi bottom ash semakin meningkat, seiring bertambahnya umur beton. Dimana kuat tekan terbesar pada substitusi bottom ash $35 \%$ yaitu $33,764 \mathrm{MPa}$.

\section{Hasil Pemeriksaan Kuat Tarik Belah Beton}

Pengujian kuat tarik belah beton dilakukan pada saat benda uji 28 hari dengan menggunakan Compression
Testing Machine untuk mendapatkan beban maksimum yaitu beban pada saat beton hancur ketika menerima beban tersebut $\left(P_{\text {maks }}\right)$ dalam satuan $\mathrm{KN}$.

Contoh Perhitungan :

Umur 28 Hari (Variasi Bottom ash 35\%):

$\begin{array}{lll}\text { Beban Maksimum }(\mathrm{P}) & & 240 \mathrm{KN}= \\ 240000 \mathrm{~N} & \\ \text { Panjang Benda Uji Silinder }(\mathrm{L}) & = & 300 \mathrm{~mm} \\ \text { Diameter Benda Uji Silinder }(\mathrm{D}) & = & 150 \mathrm{~mm} \\ \text { Kuat Tarik Belah }\left(f_{c t}\right) & \frac{2 P}{\pi L D} \\ & =\frac{2 \times 240000}{\pi \times 300 \times 150} \\ & =3,394\end{array}$

$\mathrm{N} / \mathrm{mm}^{2}=3,394 \mathrm{MPa}$

Hasil pengujian kuat tarik belah beton pada benda uji silinder dengan ukuran diameter $15 \mathrm{~cm}$ dan panjang $30 \mathrm{~cm}$ pada umur beton 28 hari dapat dilakukan uji kuat tarik belah di Laboratorium. Berikut hasil pengujian kuat tarik belah beton pada tabel 10 .

Tabel 10. Kuat Tarik Belah Beton dengan Campuran Bottom ash pada umur 28 hari

\begin{tabular}{cc}
\hline Variasi Bottom ash & Kuat tarik belah beton (MPa) \\
\hline$B A 0 \%$ & 2,545 \\
\hline$B A 25 \%$ & 2,923 \\
\hline$B A 35 \%$ & 3,253 \\
\hline
\end{tabular}

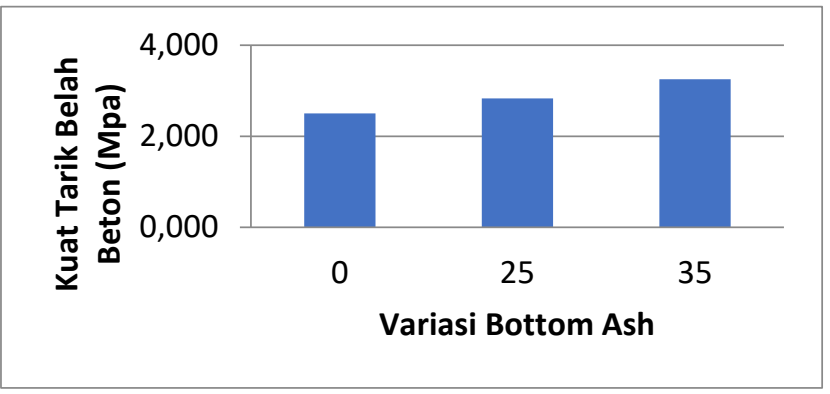

Gambar 8. Hubungan antara variasi substitusi bottom ash dengan kuat tarik belah

Dari gambar 8 menunjukkan hubungan antara variasi substitusi bottom ash dengan kuat tarik belah beton semakin meningkat. Dimana kuat tarik belah terbesar pada substitusi bottom ash 35\% yaitu 3,253 MPa.

\section{Modulus Elastisitas Beton}

Prosedur pengujian dilaksanakan berdasarkan ASTM C469, dengan benda uji berbentuk silinder dengan ukuran diameter $15 \mathrm{~cm}$ dan tinggi $30 \mathrm{~cm}$. Alat uji modulus elastisitas akan dipasang pada benda uji yang selanjutnya ditekan pada alat tekan beton (Compression Testing Machine) dimana pembacaan dial gauge vertikal dan dial gauge horizontal dilakukan setiap kenaikan $100 \mathrm{kN}$ pada pembacaan beban.

Contoh Perhitungan :

Luas penampang $(A)$

$$
\begin{aligned}
& =1 / 4 \pi \mathrm{d}^{2} \\
& =1 / 4(3,14)\left(149,8^{2}\right) \\
& =17624,366 \mathrm{~mm}^{2}
\end{aligned}
$$


Nilai strain vertikal vertikal / tinggi awal beton

$\varepsilon_{2}=$ strain vertikal awal $+($ strain vertikal kedua nilai strain vertikal awal) / (nilai tegangan kedua - tegangan awal) $\times(\mathrm{S} 2$ - nilai tegangan awal)

$=6.6379 \mathrm{E}-05+(0.000298706$ I- 6.6379E-05) / $(11.348-5.674) \times(11.23444655-5.674)$

$=0.000294059$

Penyelesaian :

S1 = nilai tegangan awal + ( nilai tegangan kedua - nilai tegangan awal ) / (strain vertikal kedua - strain vertikal awal $) \times\left(\varepsilon_{1}-\right.$ strain vertikal awal )

$=5.674+(11.348-5.674) /(0.000298706-$

$6.6379 \mathrm{E}-05) \times(0.00005-6.6379 \mathrm{E}-05)$ $=5.273948517$

Tabel 11. Hasil uji modulus elastisitas beton

\begin{tabular}{|c|c|c|c|c|}
\hline \multirow{2}{*}{$\begin{array}{c}\text { Variasi Bottom } \\
\text { ash }\end{array}$} & $\begin{array}{c}\text { Tegangan } \\
\text { (Mpa) }\end{array}$ & Regangan & $\begin{array}{c}\text { Modulus } \\
\text { Elastisitas (Mpa) }\end{array}$ & $\begin{array}{c}\text { Modulus Elastisitas } \\
\text { Teoritis }\end{array}$ \\
\cline { 4 - 5 } & & & $4700 \mathrm{Jf}^{\prime} \mathrm{c}$ \\
\hline \multirow{3}{*}{$0 \%$} & 28.086 & 0.000862927 & 24422.357 & 24908.2263 \\
\cline { 2 - 5 } & 33.254 & 0.000999001 & 26241.633 & 27103.1522 \\
\cline { 2 - 5 } & 33.863 & 0.001064892 & 26405.160 & 26497.3319 \\
\hline \multirow{3}{*}{$25 \%$} & 30.315 & 0.000895522 & 24698.739 & 25877.7578 \\
\cline { 2 - 5 } & 32.26 & 0.000993377 & 26712.380 & 26695.0070 \\
\cline { 2 - 5 } & 33.874 & 0.001064892 & 26790.745 & 26809.7821 \\
\hline \multirow{3}{*}{$35 \%$} & 32.388 & 0.001064538 & 26784.476 & 26747.9143 \\
\cline { 2 - 5 } & 33.818 & 0.001024116 & 25469.936 & 27332.0255 \\
\cline { 2 - 5 } & 34.29 & 0.001062417 & 27044.716 & 27310.1951 \\
\hline
\end{tabular}

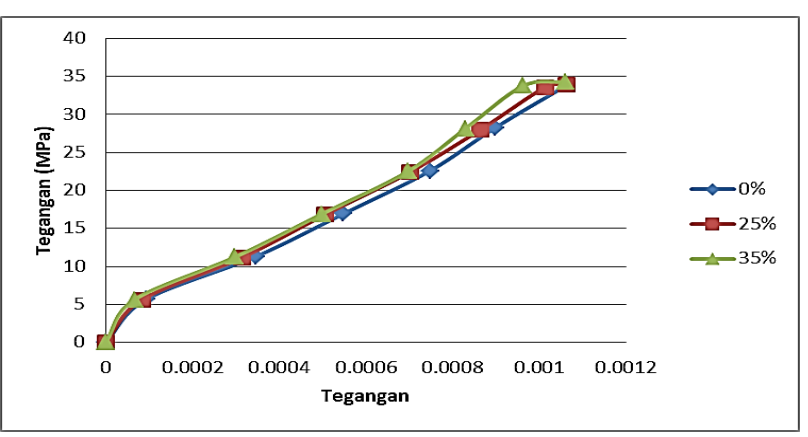

Gambar 9. Hasil pengujian modulus elastisitas beton

Berdasarkan Gambar 9 menunjukkan bahwa nilai modulus elastisitas optimal berada pada persentase $35 \%$ dengan kuat tekan 33,764 MPa dan modulus elastisitas $27044.716 \mathrm{~N} / \mathrm{mm}^{2}$ dan paling rendah berada pada persentase $0 \%$ dengan kuat tekan $31,784 \mathrm{MPa}$ dan modulus elastisitas 26405.160 $\mathrm{N} / \mathrm{mm}^{2}$.

\section{Hubungan Antara Kuat Tekan dengan Kuat Tarik Belah}

Dalam penelitian diperoleh nilai kuat tarik belah beton pada umur 28 untuk variasi bottom ash $0 \%, 25 \%$ dan $35 \%$ berturut - turut sebesar 2,545MPa, 2,923 MPa dan $3,253 \mathrm{MPa}$. Sedangkan nilai kuat tekan pada umur 28 hari untuk variasi bottom ash $0 \%$, 25\% dan $35 \%$ berturut - turut sebesar $31,784 \mathrm{MPa}, 32,538$ $\mathrm{MPa}$ dan 33,764 MPa.

\section{Variasi Fly Ash $35 \%$}

$$
\begin{array}{ll}
f_{t} & =3,253 \mathrm{MPa} \\
f_{c}^{\prime} & =33,764 \mathrm{Mpa}
\end{array}
$$

Persentase hubungan kuat tarik belah terhadap kuat tekan $9,635 \%$

Sehingga diperoleh persentase hubungan kuat tarik belah untuk variasi fly ash $0 \%, 25 \%$ dan $35 \%$ 
berturut-turut sebesar 8,007\%, 8,983\% dan $9,635 \%$ dari kuat tekan.

\section{KESIMPULAN}

Dari hasil penelitian dan pengujian laboratorium dengan benda uji silinder, komposisi beton dengan

\section{DAFTAR PUSTAKA}

[1] Darwis dan Soelarso, 2015, "Pemanfaatan Limbah Bottom Ash Sebagai Substitusi Agregat Halus Dalam Pembuatan Beton" Fondasi : Jurnal Teknik Sipil Vol.4, no.1

[2] I Wayan S, 1012, "Pemanfaatan Abu Dasar Sebagai Pengganti Sebagian Agregat Halus Pada Campuran Beton", INFRASTRUKTUR, Vol 2., no.2.

[3] Muhammad Q dan Sudarno, 2017, "Pemanfaatan Limbah Bottom Ash Pengganti Agregat Halus Dengan Tambahan Kapur Pada Pembuatan Paving", Jurnal Review in Civil Engineering, Vol. 1, no.1. menggunakan variasi bottom ash sebagai subtitusi agregat halus perbandingan ialah $1: 1,33: 2,57$.

Dari hasil penelitian dan pengujian laboratorium dengan variasi $0 \%, 25 \%$ dan $35 \%$ pada benda uji silinder, yang mencapai f'c $30 \mathrm{Mpa}$ adalah bottom ash dengan variasi $35 \%$.

[4] Mufti A, Imran, dan Rofika S, 2019, "Substitusi Parsial Agregat Halus Dengan Bottom Ash Pada Pembuatan Bata Semen", Rekayasa Sipil, Vol.13, no.1, doi: https://doi.org/10.21776/ub.rekayasasipil.2019.0 13.01 .9

[5] Aldi V, Samuel W, Djwantoro H, dan Antoni, 2016, "Penggunaan Bottom Ash Sebagai Pengganti Agregat Halus Pada Mortar HVFA", Jurnal Dimensi Pratama Teknik Sipil, Vol.5, no.2

[6] Yohanes C, Andry W, Antoni, dan Djwantoro H, 2017, "Penggunaan Bottom Ash Yang Telah Diolah Untuk Pembuatan Beton HVFA Mutu Menengah" , Jurnal Dimensi Pratama Teknik Sipil Vol.6, no.1. 